\title{
Record of Myxomycetes on Monumental Trees in Bursa City Center - Turkey
}

\author{
Fatima Touray' ${ }^{1}$ (D) C. Cem Ergül ${ }^{2}$ \\ 'Bursa Uludağ University, Institute of Science, Department of Biology, Bursa, Turkey \\ ²Bursa Uludağ University, Faculty of Arts and Sciences, Department of Biology, Bursa, Turkey
}

ORCID IDs of the authors: F.T. 0000-0003-2384-4970; C.C.E. 0000-0002-4252-3681

Please cite this article as: Touray F, Ergul CC. Record of Myxomycetes on Monumental Trees in Bursa City Center - Turkey. Eur J Biol 2019; 78(1): 40-50.

\section{ABSTRACT}

Objective: Urbanization has been reported to affect the biodiversity of myxomycetes. There is no data in the Bursa city on the diversity of myxomycete in the urban area. Therefore, we aim to determine the presence of corticolous myxomycetes on monumental trees that are located in the most populated province of Bursa city (Osmangazi and Yıldırım).

Materials and Methods: In August and October 2018, 100 barks of monumental trees located in the Osmangazi and Yıldırım) county of Bursa was collected. Moist chamber culture technique was used for the isolation and identification of the species.

Results: 16 species within 9 genera were identified. The species identified are listed, and six new species Didymium bahiense (Gottsberger), Didymium difforme (Pers.) S. F. Gray), Macbrideola martinii (Alexop. \& Beneke), Macbrideola oblonga (Pando, Lado), Physarum gyrosum (Rost.), Physarum notabile (Macbr.) were recorded for Bursa city.

Conclusion: This is the first report of corticolous myxomycetes on monumental trees in Bursa city center. It also added data and 6 new records of myxomycetes on the myxomycete biodiversity of Bursa.

Keywords: Bursa, corticolous, moist chamber, monumental, myxomycetes, turkey

\section{INTRODUCTION}

The myxomycetes, also refer to as slime molds or myxogastrid are a group of a fungus-like organism often found and occasionally common in the terrestrial ecosystem $(1,2)$. They are heterotrophic motile organisms and produce spores as a mechanism for reproduction and dispersal. Although most are tiny and need the aid of a microscope to see them, some of the myxomycetes can produce macroscopic fruiting bodies that can be easily collected (3). They feed on bacteria, and fungal spores on plant parts and decaying plant materials (decaying logs, dead leaves etc. (2), algae (4) and soil (5). Their role in the ecosystem is not well understood but since they feed on bacteria, and fungal spore they are believed to function as modulators of decomposition (1). There are about 1000 known species of myxomycetes recorded worldwide (6). The myxomycetes spore germination and successive phases, together with parts of fruiting body formation were first demonstrated by Heinrich Anton de Bary who is usually refered to as the father of mycology (7).

Little research has been done on the myxomycetes of Turkey $(8,9)$. The first report of myxomycetes in Turkey was by Lohwag (10) and Härkonen \& Uotila (11) since then, some Turkish researchers began to study myxomycetes intensively especially in recent years. In 1993 C. Ergül (12) reported 61 taxon were reported in the Marmara region in the first doctorate thesis in Turkey on myxomycetes. The number of myxomycetes species reported in Turkey so far is 252 reported in different parts of the Country (13).

This study was presented at the 4th International Scientific Research Congress with the Title "Distribution of Corticolous Myxomyctes in Bursa City Center" held on 14-17 February 2019, Yalova, Turkey. 
Hosokowa et al. (1) state that not many studies have been done on the presence and diversity of myxomycetes in the urban or city areas. Most of the work done was based on macro- organisms like birds etc. A change in biodiversity is due to the urbanization and changing of agricultural setting to the urban environment can lead to the low level of species within these areas (1). Some studies have shown that environmental pollutants like acid can affect the biodiversity of myxomycetes (14).

There have been some studies done in Bursa province on myxomycetes, but they mostly concentrate on the Uludağ region and region outside of the city (15). In other to better understand myxobiota of Bursa city, we aim to determine the diversity of corticolous myxomycetes on monumental trees that are located in the most populated province of Bursa city (Osmangazi and Yıldırım). This study provides the first report of myxomycetes in monumental trees in city center area and also records new species for the Bursa city.

\section{MATERIALS AND METHODS}

\section{Study Area}

This study was carried out in the Bursa province of Turkey, situated between $40^{\circ} 11^{\prime}$ and $44^{\circ} 12^{\prime} \mathrm{N}$ latitude and $29^{\circ} 03^{\prime}$ and $36^{\circ} 47^{\prime} \mathrm{E}$ longitude (16). Bursa is $155 \mathrm{~m}$ above sea level and has a total surface area of $10,819 \mathrm{~km}^{2}$ of which the plains covered $17 \%$ of the land, and $35 \%$ is made of mountains which are chains of mountains running from east to west (17).

Bursa is found in the Marmara region, and lies under the slope of mount Uludağ which is $2543 \mathrm{~m}$ above sea level. The Marmara region has a Mediterranean climate in its western part and a continental climate in its northern and eastern part (18). Although Bursa has the characteristics of a Mediterranean climate, it has a high total yearly precipitation and an average low temperature. The coldest months of the city is usually from January to March, and the warmest from July to September with an average annual humidity is $69 \%$, and the mean annual rainfall is 691.9 $\mathrm{mm}$ (19). Osmangazi and Yıldırım are districts of Bursa city. They are the most populated and the second most populated districts in Bursa with a population of 856,770 (Osmangazi) and 647,520 (Yıldırım). Osmangazi, the largest district in the center of Bursa, starts from the foot of Uludağ in the east with the Gökdere Valley, it reaches the Samanlı Mountain in the north with Nilufer creek and Mudanya road to the west. Yıldırım is located at the foothills of Uludağ surrounded by Gürsu and Kestel in the east, Osmangazi in the west and south, Osmangazi and Gürsu in the north. These two regions were the early settlements of the Ottomans, and there you can find a lot of historical sites. These regions are also very rich in vegetation and home to a lot of monumental trees some of which are as old as 500 years like the historical İnkaya Plane Tree (20).

These monumental trees consist of mainly Platanus orientalis, Pinus pinea, Cedrus atlantica, Cupressus sempervirens, Quercus robur, Platanus occidentalis. From the Bursa municipality report 2014 (1), there are 1219 documented monumental trees of which $65 \%$ are Platanus orientalis. About $60 \%$ of the total monumental trees are found in the two study areas, of this, 566 (47.25\%) almost $50 \%$ of the documented monumental trees are found in Osmangazi districts only 177 (14.5\%) are found in Yıldırım) district (21).

\section{Specimen Collection}

In August and October 2018, this period falls under the dry month which is a suitable time to collect bark specimens for moist chamber culture and also to prevent the existence of filamentous bacteria and fungi from over growing on the specimens during culture. We collected samples form bark of 100 monumental trees in the Osmangazi district $\left(40^{\circ} 11^{\prime} 22^{\prime \prime} \mathrm{N}\right.$ latitude and $29^{\circ} 01^{\prime} 52^{\prime \prime} \mathrm{E}$ longitude) and Yıldırım district ( $40^{\circ} 12^{\prime}$ $10^{\prime \prime} \mathrm{N}$ latitude and $29^{\circ} 01^{\prime} 52^{\prime \prime} \mathrm{E}$ longitude) of Bursa city as showed in Figure 1. Ninety of the trees the samples were collected from were located within the city center and ten from outside the city center. The collected specimens (bark) were then put in a paper bag and transported to the laboratory for the preparation of moist chamber culture as stated in Stephenson and Stempen (22). The location, tree species, date, age, and the number given to the tree by the municipality, the coordinator were recorded on each of the paper bags for each of the samples. The samples are given collection number FT.

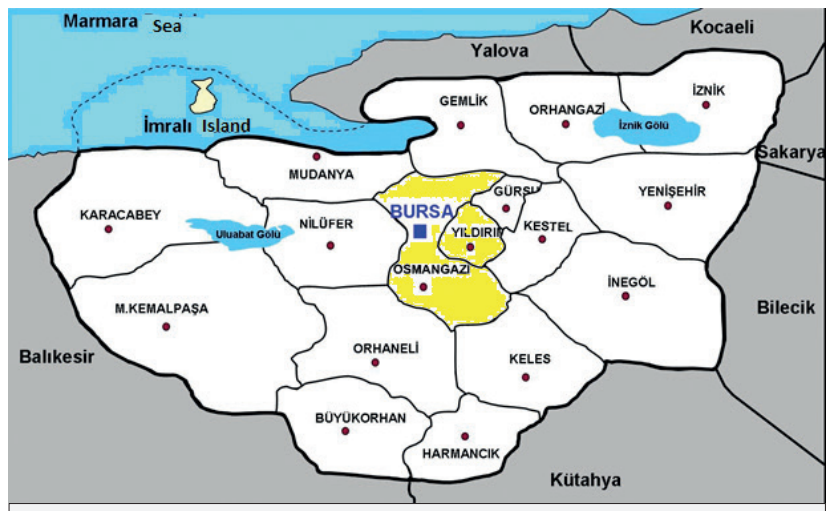

Figure 1. Map of Bursa, the Study Area indicated by the yellow color

\section{Moist Chamber Culture}

In moist chamber culture technique, a $9 \mathrm{~cm}$ diameter filter paper is placed in a petri dish; collected samples are placed on the filter. The bark is immersed in distilled water for $24-48 \mathrm{hrs}$, and then unabsorbed water is poured out. The dish is stored at room temperature $\left(20^{\circ} \mathrm{C}\right.$ to $\left.25^{\circ} \mathrm{C}\right)$. Using a stereomicroscopic (Nikon SM 800), the samples are examined daily for about a month for detection of any growth. Observations from the culture are recorded every day until the fruiting bodies are fully matured. A microscope mount is then prepared by collecting the matured fruiting bodies and putting in it a drop of Hoyer's Medium. In order to observe the microscopic characterization of the specimens, the light photomicrographs were obtained by using a Nikon DS-Fi 1 microscope equipped with a Nikon ECLIPSE 50i camera system. This helped us observed the characteristics of the capillitium, peridium, spore shapes and sizes, stalk, color, 
etc. These are the features that help in taxonomic identification or classification of the specimens. The identification of the specimens was done by using a key provided by $(2,3,23-29)$. The samples were stored in Bursa Uludağ University Biology Department, Mycobiology laboratory.

\section{RESULTS}

30 of the 100 samples cultured came out positive for one or more corticolous myxomycetes, 27 of which is Platanus orientalis, 2 Quercus robur, and 1 Platanus occidentalis. 16 species within 9 genera were identified. The distribution of species in the different orders were Physarales (38\%), Stemonitales (31\%), Trichiales (19\%), Liceales (1\%) and Echinosteliales (1\%) as shown in Figure 2. The species distribution of the 16 species identified is shown in is as follows; Cribraria violacea 12, Perichaena corticalis 10, Macbrideola cornea 7, Macbrideola martinii 2, Physarum notabile 2, Enerthenema papillatum 2, Arcyria cinerea 2, Arcyria insignis 1, Badhamia affinis 1, Didymium bahiense 1, Didymium difforme 1, Echinostelium minutum 1, Macbrideola decapillata 1, Macbrideola oblonga 1, Physarum gyrosum 1 and Physarum serpula 1. Figure 4 shows the percentages of the 9 genera identified with the most isolated being Macbrideola (25 $\%)$, Physarum (19\%), Arcyria and Didymium (13\%) and the rest

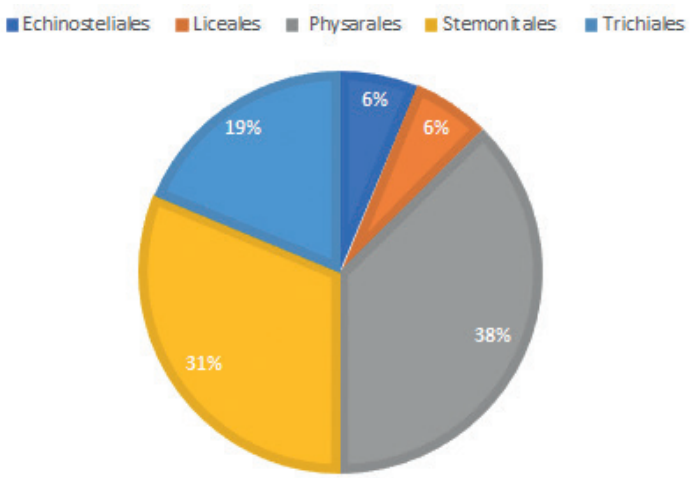

Figure 2. Distribution of orders

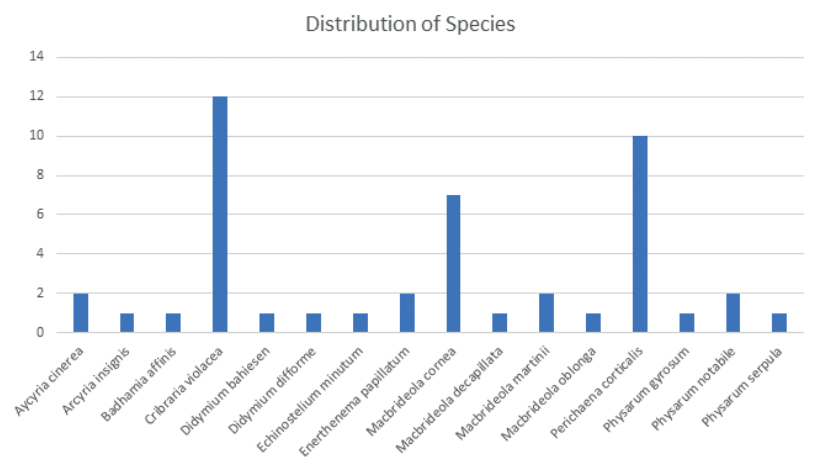

Figure 3. Distribution of species isolate

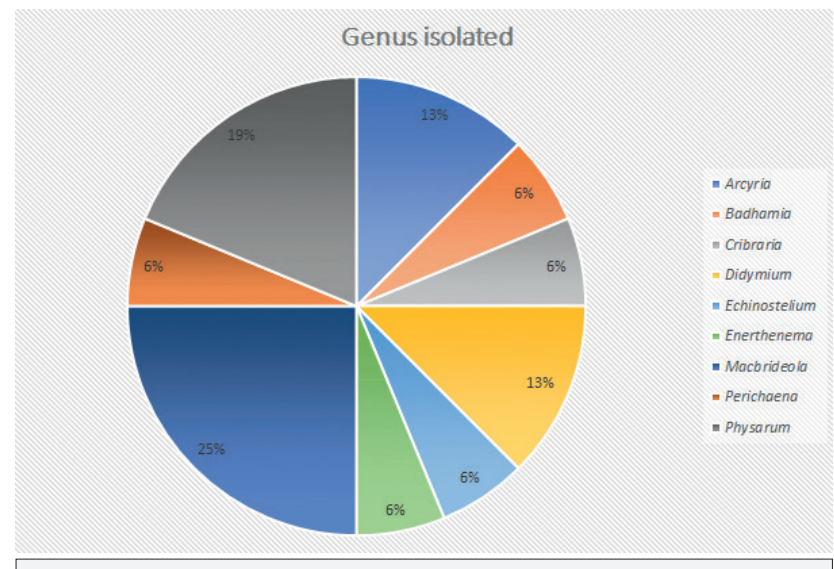

Figure 4. Distribution of corticolous myxomycetes genus

were $6 \%$. All the recorded taxa in this study are alphabetically listed below according to orders and then by species.

\section{List of Species Isolated}

\section{Echinosteliales}

Echinostelium minutum de Bary, in Rost., Mon. 2151874 (Figure 5)

Description-The sporangia are scattered, globose, white or pale pink, 40-70 $\mu \mathrm{m}$ in diameter, often nodding. Stalk longer in other species, to $500 \mu \mathrm{m}$ high, colorless or pale yellow in transmitted light. Columella is $4-20 \mu \mathrm{m}$ long. The capillitium thread forms a close, lax net around the sporangium. Spores in mass concolorous with the sporangium, colorless in transmitted light and it is about 9-12 $\mu \mathrm{m}$ in diameter. Protoplasmodium is colorless.

Specimen examined-Turkey: Bursa/ Yıldırım; Eşrefiler street near the bridge, on the bark of Platanus orientalis, 06.10.2018, FT15.

Echinostelium minutum is the most common species of Echinostelium that tends to appear on the bark than other species of the same genus. It is a cosmopolitan species commonly found in the British Isles. It can be found on bark of trees, wood

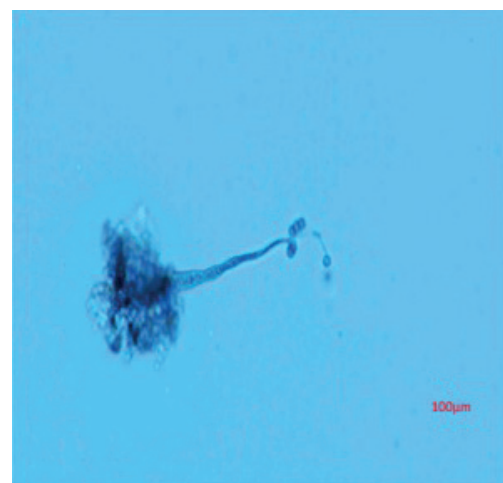

Figure 5. Sporangia, capillitium and spore of Echinostelium minutum 
and litters (23). It has been previously reported in several studies conducted in Turkey. This species was isolated from snowy twigs in a study done at the Uludağ National Park in Bursa province (15). In Kütahya province, it was isolated from the bark of living Prunus domestica (9).

\section{Liceales}

Cribraria violacea Rex. Proc. Aca. Phila. 43:393 1891 (Figure 6)

Description-The sporangia are normally deep purple to purplish bronze in color in groups (gregarious), spherical and about $0.1-0.3 \mathrm{~mm}$ in diameter, it is erect and about $0.5-1.5 \mathrm{~mm}$. The hypothallus is a small disc at the base of the stalk. The stalk is usually two 3-5 times the diameter of the sporangium, slender, tapering upwards, dark violet and under a transmitted light it appears to be red-brown inclusion in the basal part and violet. The peridium is a violet, deep cup that surrounds about $2 / 3$ of the sporangium, it is smooth or weekly pilicate, with a smooth rim merging into the flat nodes and threads of the reticulum, the nodes and meshes are usually large and irregular, and there are very dark violet lime nodes inside the cup with a diameter of 1.0-1.5 $\mu \mathrm{m}$. It has a spore mass of $7 \mu \mathrm{m}$ in diameter densely minutely warted and violet or lilac under transmitted light. The plasmodium is purplish black.

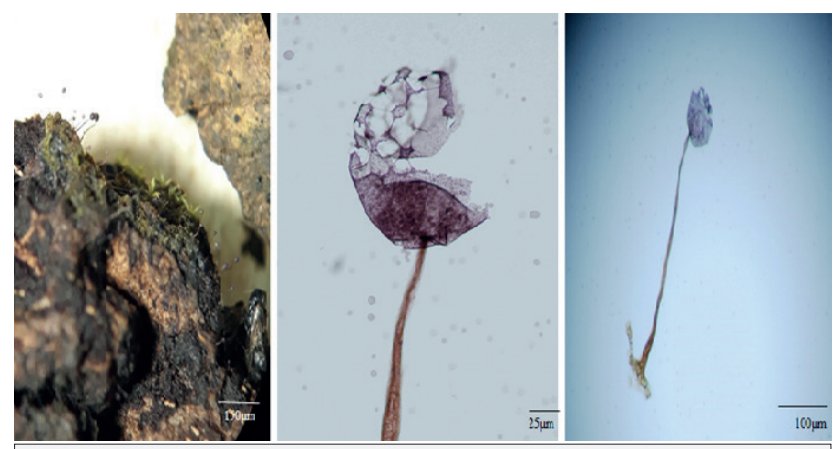

Figure 6. Sporangium, spores, capillitial nodes, peridium, hypothallus and stalk of Cribraria violacea

Specimen examined-Turkey: Bursa/Osmangazi; Behind Pınarbaşı cemetery, on the bark of Platanus orientalis, 06.10.2018, FT25. Pınarbaşı Park opposite war cemetery, on the bark of Platanus orientalis, 06.10.2018, FT42. In front of Orhangazi tomb, on bark of Platanus orientalis, 05.08.2018, FT07. Opposite Sarayönü tea garden, on the bark of Platanus orientalis, 05.08.2018, FT12. In the garden in front of Muradiye Medresesi, on the bark of Platanus orientalis, 05.08.2018, FT60. Hamzabey road, on the bark of Platanus orientalis, 05.08.2018, FT74. Next to Çekirge Police center, on bark of Platanus orientalis, 05.08.2018, FT23. I. Murat road, behind Mutlu hotel, on the bark of Platanus orientalis, 05.08.2018, FT03. Çukurca village between the intersection of Çalı street and Ocak street, on the bark of Quercus robur, 06.10.2018, FT34. Sultan Palace (Hünkar Köşkü) road, on the bark of Platanus orientalis, 06.10.2018, FT48. Sultan
Palace road, on the bark of Platanus orientalis, 06.10.2018, FT22.

Cribraria violacea is found on dead wood, the bark of dead and living trees, and mosses. Its bright violet color makes its identification easy. This species is cosmopolitan and widely distributed in North America and Switzerland (23). First reported in Turkey by, (11). It has now been reported in several parts of Turkey as explained in checklist myxomycetes in Turkey (13). It was first reported in Bursa by Ergül (12) on the bark of Platanus orientalis. In the Hatay region of Turkey, Cribraria violacea was isolated from the bark of coniferous woods at a university campus, using the moist chamber technique (30), It was also reported from the bark of Pinus brutia from the İzmir region (31) also isolated in Konya on the log of Ficus sp., Pinus nigra and bark of Malus sp. (32). This species was isolated from 11 samples in our study all of which happen to be Platanus orientalis.

\section{Physarales}

Badhamia affinis Rostaf., Mon. 143. 1874. (Figure 7)

Description-Sporangia short of plasmodiocarps, gregarious, sessile or short-stalked, subspherical to discoid, often depressed in the center, $0.5-1.0 \mathrm{~mm}$ wide, $2.0 \mathrm{~mm}$ long, pale grey to whitish, usually with a darker base. Hypothallus sometimes black from absorbed dirty particles. Stalk if present, short, grooved and black. Peridium single, colorless above, brown below, with flake-like, scanty or abundant incrustations. Capillitium tube filled with white lime, poorly branched and hardly or no interconnected. Spores in mass brown, pale lilacbrown in transmitted light, spherical, 12-15 $\mu \mathrm{m}$ in diameter, densely covered with pale warts. Plasmodium creamy.
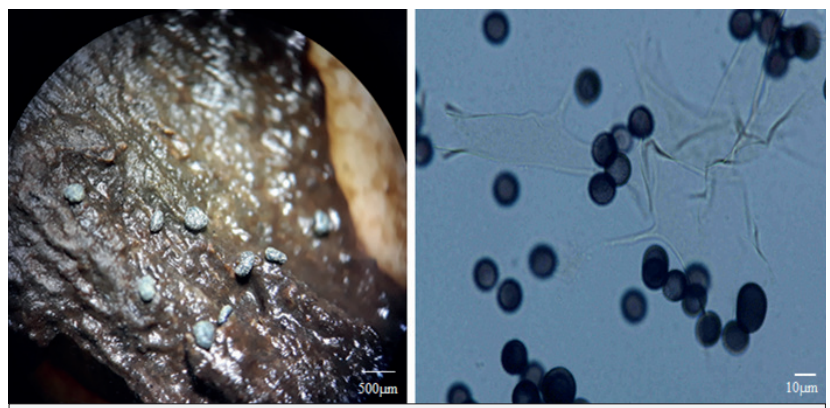

Figure 7. Capillitium, spores and plasmodiocarps of Badhamia affinis

Specimen examined-Turkey: Bursa/ Osmangazi; Timurtaşpaşa park, on bark of Platanus orientalis, 05.08.2018, FT05.

Found in Australia, Japan and in most parts of Europe and especially in the mountains (23), Badhamia affinis is a rare species of myxomycetes in Turkey. It was first reported in Turkey by, (11). This species is mostly found on the bark of living and dead trees, found around Great Britain, Greece, Canada and widely distributed in America (2). In our study, it was isolated from the bark of Platanus orientalis only one sample. 
Didymium bahiense Gottsberger, Nova Hedw. 16: 365. 1968, em. Nann-Brem., Proc. K. Ned. Akad. Wet. C. 75: 360. 1972 (Figure 8)

Description-Sporangia in groups, stalked, $0.8-2.0 \mathrm{~mm}$ tall, discoid but reflexed around the stalk forming a deep umbilicus and appearing sub-globose, $0.2-0.7 \mathrm{~mm}$ in diameter, white or pale grey. Hypothallus small discoid, dull and almost black. Stalk 2-3 times longer than the width of the sporangium, tapering but keeping somewhat erect dark at the base and paler above, in transmitted light it is translucent red-brown, limeless. Peridium mainly thin, colorless or pale-yellow with a thickened basal plate on which crystalline lime in the form of a pseudocollumela is present. Capillitium tubules abundant, dichotomously branched, dark or pale brown with the exception of pale ends and small dark swellings. Spores are dark brown in mass, pale brown to dark lilac-grey in transmitted light (9) 10-12 (14.5) $\mu \mathrm{m}$ in diameter, covered with warts.
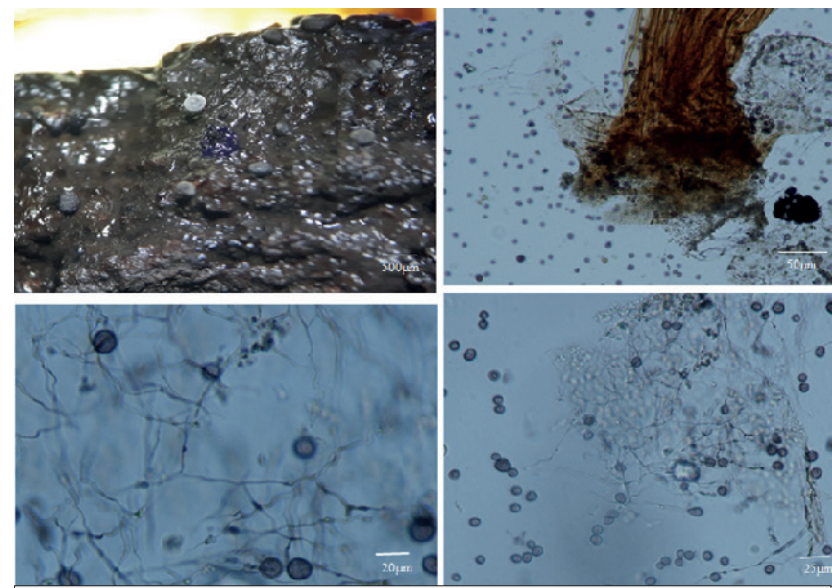

Figure 8. Capillitium tubules, spore, sporangia of Didymium bahiense

Specimen examined-Turkey: Bursa/Osmangazi; In front of Çekirge police center, on the bark of Platanus orientalis, 05.08.2018, FT28.

Didymium bahiense is cosmopolitan and commonly found on dead leaves, and plants refuse (23). First reported in Turkey Kastamonu province, on the bark of Creatagus sp. (33). In our study it was isolated on the bark of Platanus orientalis. This species has only been reported a few times in Turkey (13).

Didymium difforme (Pers.) S. F. Gray, Nat. Arr. Brit. PI. 1: 571. 1821 (Figure 9)

Description-Sporangia sessile gregarious, 0.3-1.0 mm wide, 0.3-1.0 mm tall, almost round, oval or oblong seen from above, white or ochraceous. Hypothallus is inconspicuous. Peridium double, layers usually distant, a smooth outer crust of densely packed small lime crystals, the inner membranous, colorless, pale purple, shining. Columella absent. Capillitium tubules sparse, stiff, thick, sparsely dichotomously branched,

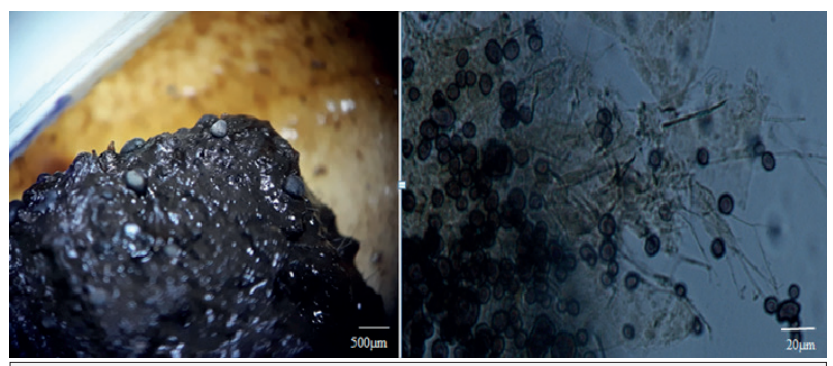

Figure 9. Capillitium tubules, sporangia, spore of Didymium difforme

exceptionally a lax net is formed lilac-brown or almost colorless, often with bread like swellings, sometimes with large vesicle-like partitioned swellings in which lime is occasionally present, weakly connected to the peridium above, sometimes connected somewhat longer to the base. Spores in mass deep black, dark purple-brown in transmitted light, paler on one side, roughly spherical, rarely ovoid, 11-14 $\mu \mathrm{m}$ in diameter, densely covered with fine warts. Plasmodium colorless or grey.

Specimen examined-Turkey: Bursa/Osmangazi; In front of Çekirge police center, on the bark of Platanus orientalis, 05.08.2018, FT28.

It could be found on rotting plant refused and dead leaves occasionally in bark culture and one of the commonest myxomycetes that can be found in Europe (29). Didymium difforme has been reported in Turkey before in several studies (13). We isolate it on the bark of Platanus orientalis. Although similar to a few other species of Didymium like D. commatum, $D$. tubulatum, $D$. trachysporum, in our study the characteristics of our sample is that of Didymium difforme. A similar study (31), reported $D$. difforme in leaves of Pinus brutia in Izmir province using moist chamber and also reported in the Konya province on decaying wood of Pinus nigra (9).

\section{Physarum gyrosum Rost., Mon. 111. 1874 (Figure 10)}

Description-Plasmodiocarps usually in crowded rosettelike or reticulate groups, sessile about $1.0 \mathrm{~mm}$ tall, laterally compressed, usually curved sometimes ring-shaped, 0.2-0.4 $\mathrm{mm}$ wide and up to few $\mathrm{mm}$ long, reddish, rosy-grey or ashcolored. Hypothallus translucently red-brown, sometimes curving up under a plasmodiocarp as a tiny stalk. Peridium single, encrusted with rosy or red lime, crumbling away at the apex. Capillitium a dense, elastic, network of delicate hyaline threads with numerous large, spike-like, transverse, white nodes and smaller fusiform nodes. Spores dark brown in mass, pale violaceous brown by transmitted light, minutely spinulose, 7-10 $\mu \mathrm{m}$ in diameter. Plasmodium white changing to yellow upon exposure to light.

Specimen examined-Turkey: Bursa/Osmangazi; In front of Çekirge police center, on the bark of Platanus orientalis, 05.08.2018, FT28. 

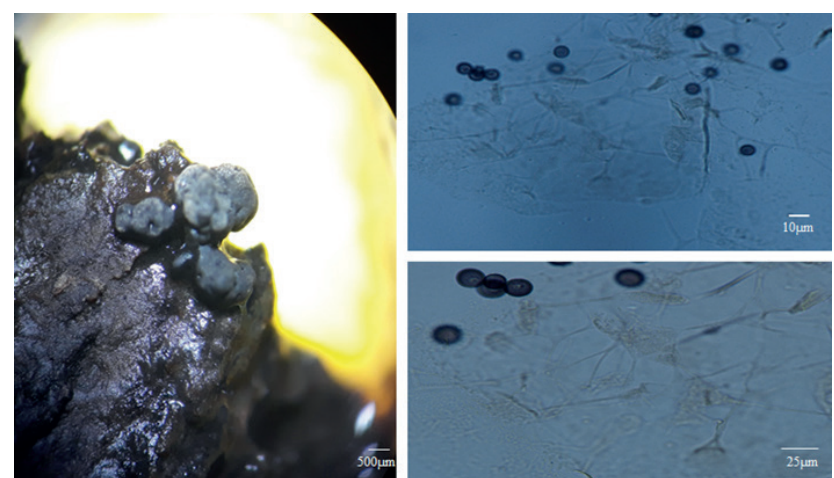

Figure 10. Plasmodiocarp, hyaline threads, and spore of Physarum gyrosum

Mostly found in Germany (29), Physarum gyrosum is not distributed in Turkey, it has only been reported in recent years first by Demirel \& Kaşık (34) and then later in the Konya province on the decaying wood of Pinus nigra and Juniperus sp. (33). This species is said to be a transitional form between Fuligo and Pysarum by Lister, Macbride and Martin stated that it resembles a large sessile form of Physarum polycephalum a species usually used in the laboratories (29).

Physarum notabile Macbr., N. Am. Slime-Moulds ed. 2. 80. 1922 (Figure 11)

Description-Stalked sporangia, occasionally sessile or forming short plasmodiocarps, gregarious often in large developments, globose to kidney-shaped, usually with 2-10 sporangia joined by a stalk $0.3-1.0 \mu \mathrm{m}$ in diameter. Hypothallus continuous under the group, white. Stalk if present often misshaped, deeply plicate - furrowed, opaque, dark or covered with white calcareous granules. Capillitium is abundant with large angular white nodes connected by long colorless threads. Spores are black in mass, olivaceous brown in transmitted light, 10-11.5 $\mu \mathrm{m}$ in diameter, minutely warted. Plasmodium is white or pale grey.
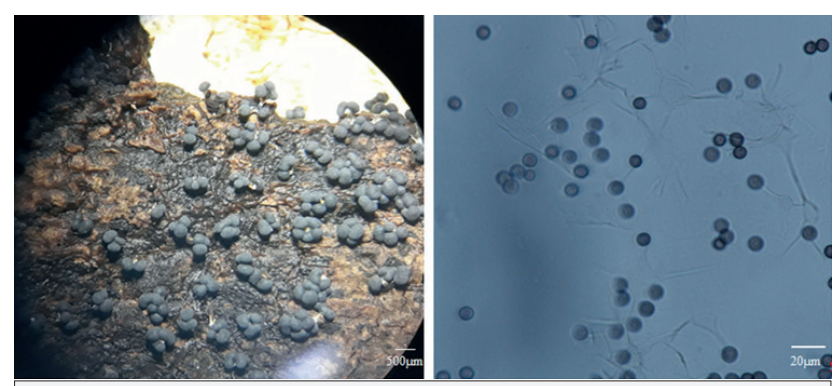

Figure 11. Sporangia, capillitium with nodes, and spore of Physarum notabile

Specimen examined-Turkey: Bursa/Osmangazi; Behind Pınarbaşı cemetery, on the bark of Platanus orientalis, 06.10.2018, FT25, Yıldırım; Sultan Palace road, on the bark of Platanus orientalis, 06.10.2018, FT22.
Physarum notabile commonly found on dead wood and occasionally on the bark of living trees (23), has previously been reported in Turkey checklist (13). It was isolated on the bark of Platanus sp. in Kastamonu province (33), just like in our study it was isolated on Platanus orientalis. A study by Ocak \& Konuk (9), has reported Physarum notabile in Konya and Kütahya regions on the bark of Pinus nigra and Prunus domestica. The large fruiting's and how the sporangia are clustered makes it possible for its identification in the field (23).

Physarum serpula Morgan, Jour. Cinc. Soc. Nat. Hist. 19: 29. 1896 (Figure 12)

Description-Plasmodiocarpous are forming rings, lines, or simple network; sometimes the strands fused laterally so that a broad fruiting surface is formed, $0.2-0.4 \mathrm{~mm}$ wide, often interspersed with globose sporangiate fruiting's, dull yellow of ochraceous, rarely bright yellow, fading. Peridium single, thin or closely incrusted lime granules, without calcareous scales. Capillitium dense calcareous, the nodes numerous, large angular, branching, pale yellow or whitish, connected by short hyaline threads or broad limy strands. Spores globose, dull black in mass, dark brown in transmitted light, minutely warted with a paler and smoother area on one side, $10-13 \mu \mathrm{m}$ in diameter. Plasmodium at maturity is greenish yellow.
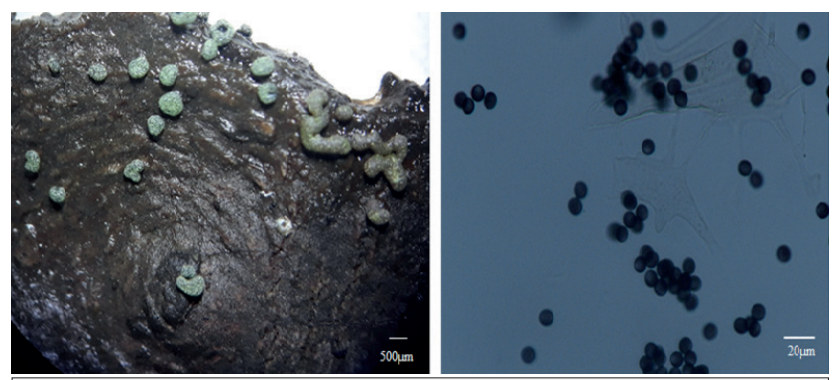

Figure 12. Plasmodiocarp, spore and a capillitium of Physarum serpula

Specimen examined - Turkey: Bursa/Yıldırım; Sultan Palace road, on the bark of Platanus orientalis, 06.10.2018, FT66.

Physarum serpula is a rare species in Turkey. It was first reported in Bursa province on the bark of Quercus robur (18). Recently it has been reported in the Kütahya region on the bark of living Pyrus communis and Malus sp. (9). In our study, it was isolated from the bark of the Platanus orientalis tree. Usually found on dead leaves, bark and lichens, it is closely related to $P$. decipiens and $P$. auriscalpium, and they are normally confused for each other. Although they may be closely related, $P$. decipiens have a more sporangiate and more badhamoid than theother two; also P. auriscalpium has prominent limescale (23). This species of Physarum is very uncommon due to it being inconspicuous (23). 


\section{Stemonitales}

Enerthenema papillatum (Per.) Rost., Mon. App. 28.1876 (Figure 13)

Description-Sporangia disperse or crowded, spherical 0.4- 0.7 $\mathrm{mm}$ in diameter, dark brown to almost black. Hypothallus is discoid or continuous under a group. Stalk consisting of a net of opaque fibers, shorter or nearly as long as the sporangium, black. The columella is black extending to the apex of the sporangium. Capillitium consisting of long dark flexuous threads which are connected to the top of the columella dichotomously branched 1-3 times in the outer part. Spore dark brown to almost black, grey-brown in transmitted light and 10-12 $\mu \mathrm{m}$ in diameter with fine warts.
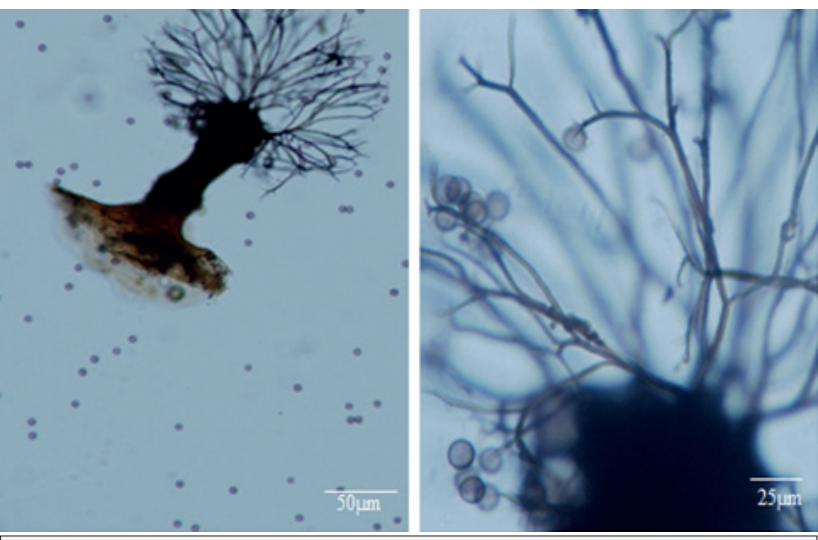

Figure 13. Spore, capillitium. Sporangia characteristic of Enerthenema papillatum

Specimen examined-Turkey: Bursa/Osmangazi; In the garden in front of Muradiye Madrassa, on the bark of Platanus occidentalis, 05.08.2018, FT58, Çekirge road in front of Çelik Palas, on the bark of Platanus orientalis, 05.08.2018, FT89.

Enerthenema papillatum is typically found on the dead wood and bark of living trees. Mostly found in America, Canada, Chile, etc. (29). In our study, it has been isolated from the bark of Platanus orientalis and Platanus occidentalis. This species of Enerthenema has been reported in Turkey since 1983 by Härkönen \& Uotila (11) after which it was reported by other researchers in Turkey (13). A study done by Ergül \& Akgül (15), reported Enerthenema papillatum from the Uludağ region of Bursa. A similar study conducted in İzmir has also reported Enerthenema papillatum on the bark of Pinus brutia (31).

Macbrideola cornea (G. Lister \& Cran.) Alexop., Mycologia 59:112.1967 (Figure 14)

Description-Sporangia scattered or in groups, globose, dark brown, $0.3-2.0 \mathrm{~mm}$ high, and $0.1-0.3 \mathrm{~mm}$ in diameter. The Hypothallus is small red-brown or yellow disc. Its stalk is slender, straight, sometimes yellow, red-brownish, honey color at the base, dark above, distinctly hollow, becomes darker upward and

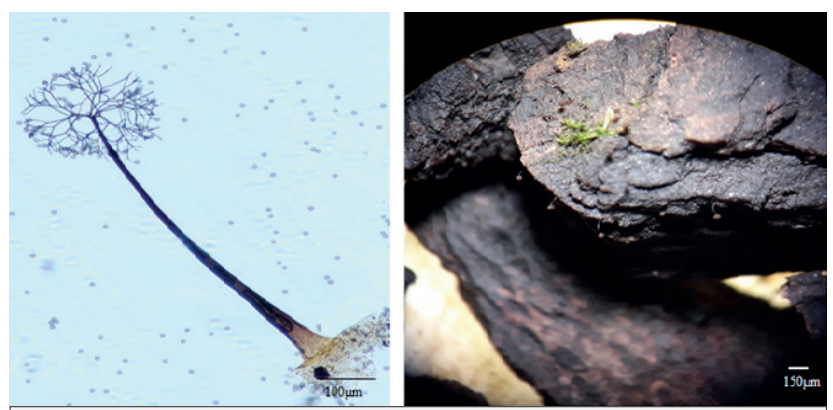

Figure 14. Sporangia, spore, capillitium of Macbrideola cornea

its $1 / 2$ to $2 / 3$ of the total height. The peridium is fugacious with the exception of a collar around the sporangium. The columella is brown reaching about the center of the sporangium dividing into the main capillitium branches. Capillitium is dichotomously branching, dark brown, usually 1-3 times, tapering outwards but not very thin at the periphery, branches usually covered with a colorless layer. It has spores that are mass dark brown, lilac-brown or grey-brown in transmitted light, minutely warted and $8-9 \mu \mathrm{m}$ in diameter. Plasmodium is normally colorless.

Specimen examined-Turkey: Bursa/Osmangazi; Pınarbaşı park in front of picnic tables, on bark of Platanus orientalis, 06.10.2018 FT29, In the garden in front of Muradiye Madrassa, on bark of Platanus occidentalis, 05.08.2018, FT58, I. Murat road, opposite Mutlu hotel, on bark of Platanus orientalis, 05.08.2018, FT03, Çeltik Village Yeniyol street, on bark of Platanus orientalis, 06.10.2018, FT18, Yıldırım; Mollaarap plane tree road, on bark of Platanus orientalis, 06.10.2018, FT09, Sultan Palace road on bark of Platanus orientalis, 06.10.2018, FT20.

Macbrideola cornea found on the bark of trees, it has been reported in some European countries like France, Scotland, and Germany (2). Reported in several parts of Turkey as explained in the checklist of myxomycetes in (13). This species has been reported before from bark of trees in the city of Bursa by Ergül \& Dülger (35). In İzmir it was isolated on Pinus brutia (31) and in Konya from bark of Pinus nigra (9). In our study, we isolated Macbrideola cornea form several Platanus orientalis and $P$. occidentalis. It can be differentiated from the Paradiacheopsis by its hollow stalk (23).

Macbrideola decapillata H. C Gilbert, Univ. lowa Stud. Nat. Hist 16: 158. 1934.lowa, (Figure 15)

Description-Sporangia is stalked, globose, scattered, dark brown, 175-350 $\mu \mathrm{m}$ in height, 50-100 $\mu \mathrm{m}$ in diameter. The stalk is slender, translucent, yellow at the base, brown above $125-250 \mu \mathrm{m}$ long. Peridium is leaving a small collar. Columella reaching to three-quarter of the sporangial diameter rounded at the tip or bearing a few short branches. Capillitium is often absent but never more than a few filaments arising from the columella towards the outside. Spores in mass dark brown, violet brown in transmitted light, 7-9 $\mu \mathrm{m}$ diameters, unevenly warted. Plasmodium colorless. 

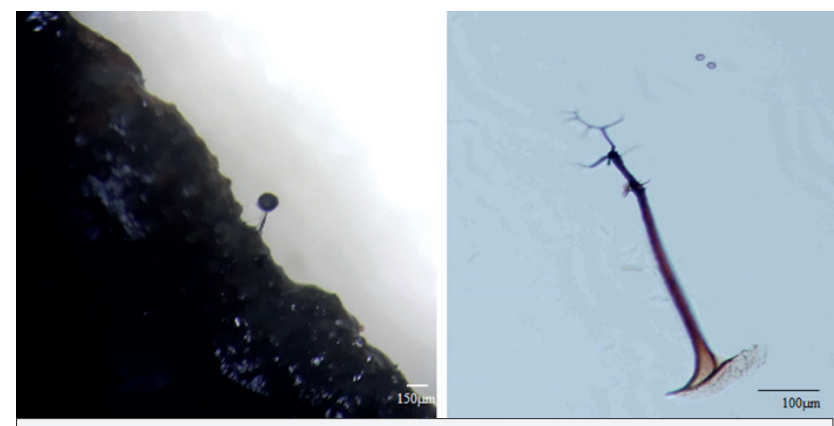

Figure 15. Sporangia, spore and capillitium of Macbrideola decapillata

Specimen examined-Turkey: Bursa/Osmangazi; Demirkapı community assisted police volunteer training center, on the bark of Platanus orientalis, 06.10.2018, FT54.

Macbrideola decapillata was isolated from a tree of Platanus orientalis in this study. This species has been reported a few times in other studies conducted in other parts of Turkey (13) and also recorded in North and Central America and Spain. Mostly found bark of living trees in the moist chamber (23), Macbrideola decapillata can be easily distinguished from Macbrideola cornea and Macbrideola scintillans by the absent of capillitium, long thin stalk, dull spore mass which dispersed quickly leaving only the stalk and columella $(2,23)$.

Macbrideola martinii (Alexop. \& Beneke) Alexop., Mycologia 59: 114. 1967. (Figure 16)

Description-The sporangia are scattered, brown, globose, minute, $0.08-0.15 \mathrm{~mm}$ in diameter, a total height of $0.5-0.6 \mathrm{~mm}$. Its peridium is completely evanescent. The stalk is brownishyellow or honey at the base, brown upwards and continues up to the center of the sporangium as columella, and it is slender. The columella is an extension from the stalk reaching about the center of the sporangium and dividing into main capillitium branches. The capillitium arises from the tip of the columella, it is lax, consisting of three or four slender, brown branches which are fork dichotomously three or four times with no anastomoses. The spores are brown in mass and violet-gray by transmitted light, minutely verrucose, 7-8 $\mu \mathrm{m}$ in diameter. Its plasmodium is unknown.
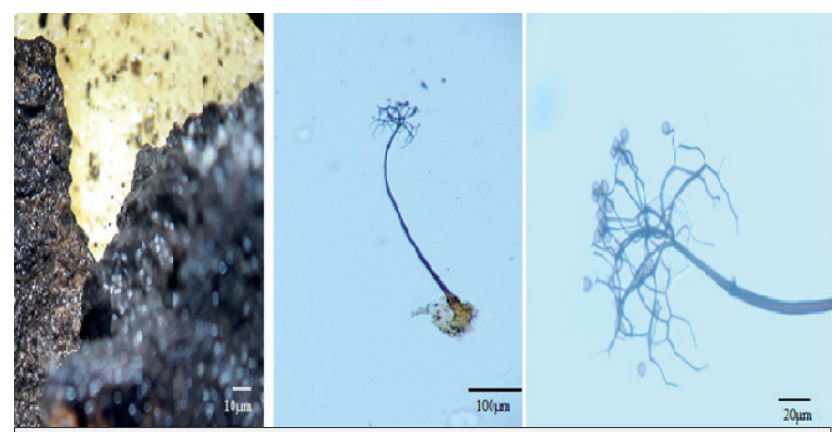

Figure 16. Sporangia, spore and capillitium of Macbrideola martinii
Specimen examined-Turkey: Bursa/Osmangazi; In front of Orhangazi tomb, on the bark of Platanus orientalis, 05.08.2018, FT07, Çekirge road in front of Çelik Palas, on the bark of Platanus orientalis, 05.08.2018, FT89.

Found on dead bark of trees in a moist chamber, distributed in Jamaica and Dominica (2), Macbrideola martini has been reported only twice in Turkey according to checklist (13). Isolated from the bark of the Quercus tree in İstanbul, using moist chamber (8). In this study, it has been isolated from barks on the bark of Platanus orientalis. Its slender tips of the capillitium make it different from Macbrideola cornea (2).

\section{Macbrideola oblonga Pando, F., Lado, C. 1988: (Figure 17)}

Description-Sporangia are scattered $0.4-0.9 \mathrm{~mm}$ tall. Hypothallus is wide and reddish. The stalk tapered, $16-25 \%$ of the total height, reddish, translucent at the base. Sporotheca mostly ellipsoidal, rarely sub-globose or cylindrical, burnt umber, $0.20-0.45 \mathrm{~mm}$ diameter. Peridium is remaining as a transparent, red-brown collar. Columella is reaching almost to the apex of the sporotheca. Capillitium arising from along the length of the columella, dichotomously branched, ending free or united near the surface, small sporocarps with few or no anastomoses, somewhat thick, brown, hardly attenuated outwards, free ends blunt, slightly swollen or club-shaped. Spore-mass brown. Spores globose, pale brown, 10.5-11.5 (12.5) $\mu \mathrm{m}$ diameter, densely, regularly verrucose.
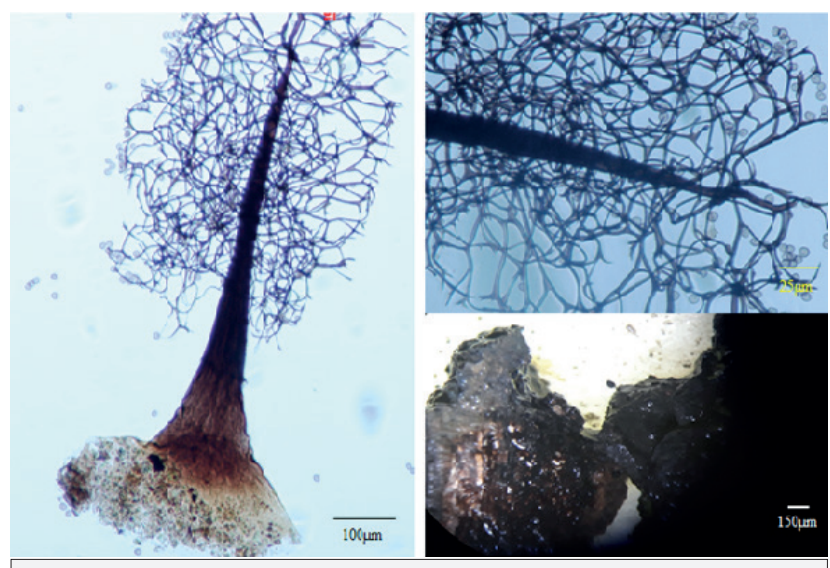

Figure 17. Sporangia, spore and capillitium of Macbrideola oblonga

Specimen examined-Turkey: Bursa/Osmangazi; Çeltik Village Yeniyol street, on bark of Quereus robur, 06.10.2018, FT45.

Macbrideola oblonga species is rare and commonly found in the desert of Western Kazakhstan (9). It has never been reported in Turkey until recently by Ocak \& Konuk (9) from the bark of Pinus nigra tree in the Konya region of Turkey. In the city of Bursa and the Marmara region of Turkey, this is the first time it has ever been isolated and reported from the bark of Quercus robur tree. 


\section{Trichiales}

Arcyria cinerea (Bull.) Pers., Syn. Fung.:184. 1801. (Figure 18)

Description-Sporangia scattered or in groups, usually cylindrical or subconical, $0.5-0.8 \mathrm{~mm}$ in diameter, almost white, pale gray, beige or rarely ochraceous. Hypothallus is extending under the whole group but discoid under isolated sporangia. The stalk is $0.2-1.5 \mathrm{~mm}$ long usually darker than the sporangium, filled with round cells $14-22 \mu \mathrm{m}$ in diameter. The peridium is fugacious, small, yellowish, and translucent and the surface is smooth or almost smooth. The capillitium net is usually small meshed, rarely rather wide-meshed, mainly expanding upwards to 1.5 times the original height, firmly connected to the cup, strongly warted or spinulose at the base and covered with spines at the periphery. The spore is $6-8 \mu \mathrm{m}$ in diameter, almost colorless in transmitted light, covered with fine warts. Plasmodium is usually white and sometimes grey or greenish.
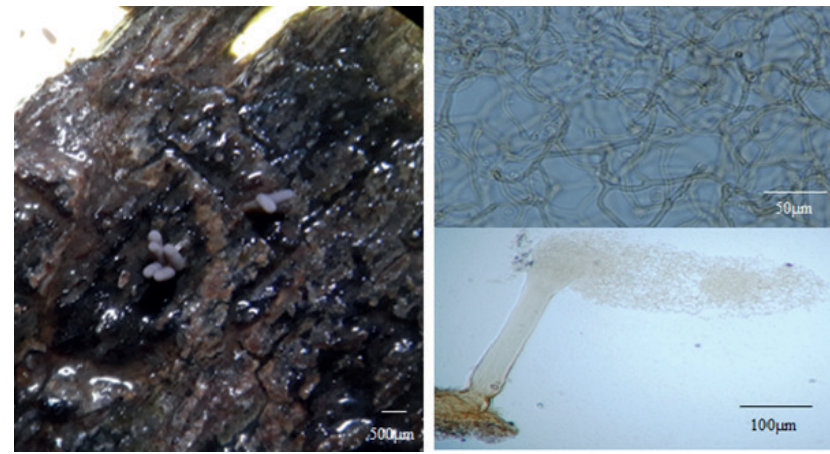

Figure 18. Capillitium, Sporangium, Stalk and spore characteristics Arcyria cinerea

Specimen examined-Turkey: Bursa/Osmangazi; Burton visualization center near Çelik Palas, on the bark of Platanus orientalis, 05.08.2018, FT84, Sultan Palace road, on the bark of Platanus orientalis, 06.10.2018, FT48

Arcyria cinerea has been isolated from Platanus orientalis trees in our study. In Bursa-Uludağ, it was isolated from fallen and rotten trees (15). In a similar study in Konya, Arcyria cinerea was isolated from the bark of living Pinus nigra (9), Platanus sp., Malus sp. and Pinus nigra (32). This species has also been reported by some researchers in Turkey as described in (13). Distributed in France and the British Isles, it is common on logs, dead wood, and bark of living trees $(2,23)$. In bark culture, this species can be mistaken for Arcyria pomiformis. However, it can be differentiated by its development of pinkish plasmodium unlike that of $A$. pomiformis which is yellow.

Arcyria insignis Kalchbr. \& Cooke, in Kalchbr., Grevillea 10:143. 1882 (Figure 19)

Description-Sporangia scattered, gregarious, shortly ovate with an acute apex, pale rose, flesh color or pale salmon 0.5-1.5 $\mathrm{mm}$ tall. The stalk is short $0.7 \mathrm{~mm}$ high brownish-orange, and the base filled with spore-like or sub-globose cells. Peridium is remaining as a shallow saucer shape cup. Capillitium is pale yellow to colorless threads, marked with bands and spines arranged in a loose spiral, in part minutely spinulose to nearly
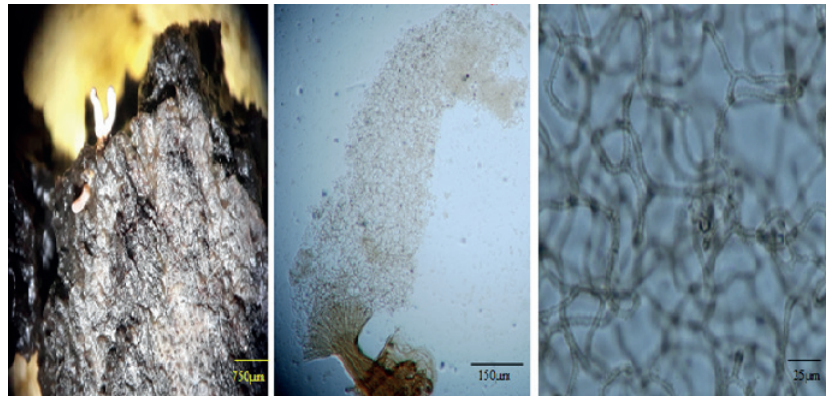

Figure 19. The capillitium, spore, and sporangium of Arcyria insignis

smooth attached to the calyculus. Spores are yellowish pinkish in mass and colorless in transmitted light with scattered groups of warts, $8-10 \mu \mathrm{m}$ in diameter.

Specimen examined-Turkey: Bursa/Osmangazi; In front of Çekirge police center, Platanus orientalis, 05.08.2018, FT28.

Arcyria insignis was previously reported in Bursa by Ergül \& Akgül (15) from decay logs of Fagus orientalis and on bark and branches of Pinus brutia (31). In our study, it was isolated from the bark of Platanus orientalis. Distributed in New Zealand, the Mediterranean region and Central Europe, it is commonly found on fall branches (23).

Perichaena corticalis (Batsch) Rost., Mon. 293. 1875 (Figure 20)

Description-The sporangia are mainly sub-globose or globose, sessile, gregarious, hemispheric, rarely short ring-shaped plasmodiocarps, 0.2-1.0 $\mathrm{mm}$ in diameter, bright reddish brown to nearly black, undulating line around the middle indicates the position of the lids. The Hypothallus is extending under the whole group, thin brown. The Peridium is thick, double and
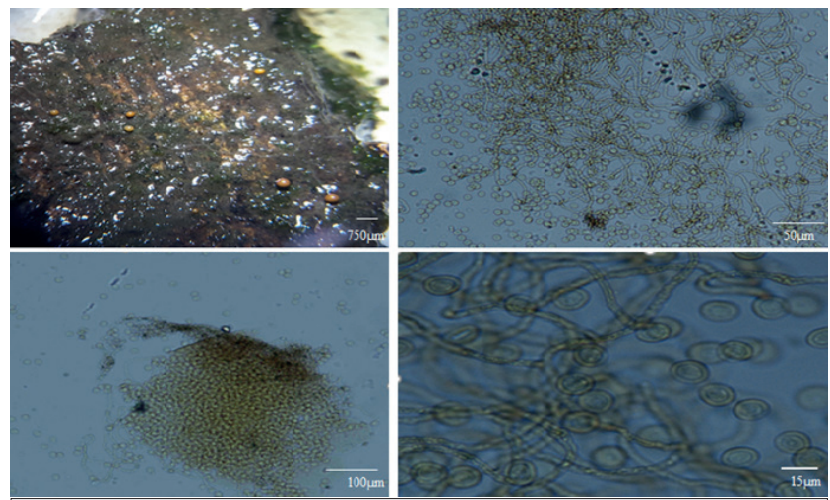

Figure 20. Spore mass, peridium, capillitium and sporangia of Perichaena corticalis 
the outer layer often impregnated with granular materials and sometimes calcareous, connected to the membranous inner layer, opening with a convex lid leaving a persistent basal cup. Capillitium is abundant, scanty, 1.5-4.0 $\mu \mathrm{m}$ in diameter, slender or simple branched yellow threads, irregular compressed, angled or constricted minutely warted or spiny, rarely nearly smooth. Its spores are in mass bright yellow or golden yellow, yellow in transmitted light 10-14 $\mu \mathrm{m}$ in diameter, with small pale warts. Plasmodium is usually watery gray or brown. Common in bark or dead trees and moist chamber culture of barks.

Specimen examined-Turkey: Bursa/Osmangazi; Behind Pınarbaşı cemetery, on the bark of Platanus orientalis, 06.10.2018, FT36. Pınarbaşı Park in front of picnic tables, on the bark of Platanus orientalis, 06.10.2018 FT29. Pınarbaşı Park, on the bark of Platanus orientalis, 06.10.2018 FT44. Pınarbaşı Park opposite war cemetery, on the bark of Platanus orientalis, 06.10.2018, FT42. In front of Orhangazi tomb, on the bark of Platanus orientalis, 05.08.2018, FT07. Hamza Bey road, on the bark of Platanus orientalis, 05.08.2018, FT75. In front of Çukurca mosque, on bark of Platanus orientalis, 06.10.2018, FT91. Çeltik Village Yeniyol street, on the bark of Platanus orientalis, 06.10.2018, FT18. Sultan Palace road, on bark of Platanus orientalis, 06.10.2018, FT10. Sultan Palace road, Platanus orientalis, 06.10.2018, FT20.

Mostly found on dead wood and bark of living trees. Perichaena corticalis has been mainly distributed in the Americans and Europe. This species of Perichaena has been reported in Turkey in the 1980s by Härkönen \& Uotila (11) and also, reported in the bark of trees collected from the Görükle Campus in Bursa (35). In İzmir, it was reported to have been isolated form branch of Pinus brutia (31), and in Kütahya province, it was isolated from the bark of living Prunus domestica (9). In our study, we isolated Perichaena corticalis on the bark of Platanus orientalis.

\section{DISCUSSION}

The species isolated so far has been reported previously in Turkey. Six of the species (Physarum gyrosum, Physarum notabile, Didymium bahiense, Didymium difforme, Macbrideola martinii, and Macbrideola oblonga), are new records for the city of Bursa. This study also reports the first Macbrideola oblonga in the Marmara region of Turkey. Cribraria violacea is the most frequently isolated species isolated from 12 (40\%) of the barks of monumental trees. There was no co-existence between the species but the Enerthenema papillatum were found together with the Macbrideola spp. The species isolated were on the barks of Platanus orientalis 27, Platanus occidentalis 1 and Quercus robur 2 . The texture of the tree bark might primarily be a factor on the occurrence of different myxomycetes on a bark of tree, Platanus sp., Quercus sp., etc. tends to store water and nutrients required for the growth of myxomycetes (36), in our study, even though samples were collected from other plants species, production was only observed on Platanus sp. and Quercus sp.

The yield of corticolous myxomycetes is low compared to studies done in the Uludağ region, where 35 species were isolated from
61 localities (15). It could be that the Uludağ region is a more natural ecological environment than the city center area. Some studies indicate that there is an ecological simplification in the urban environment leading to the decrease in some of these species (37). A similar study in Spain reported a significant difference between the diversity of myxomycetes in the city are and outside the city area. More myxomycetes were isolated from outside city area due to the decrease in environmental pollutants (14). Not all studies agree to the low yield of myxomycetes in the urban areas. A study by (1) founds no significant difference between the city and outside the city area.

Even though the sample side from the outside city is not much, the species isolated from both areas are the same except for Macbrideola oblonga which was isolated from the outside city only. This species was isolated from a village in Konya province (9), and in Spain, a study that compares the effect of environmental factors on the presence of myxomycetes found Macbrideola oblonga in a less polluted environment (14).

Some of the species are more tolerant of pollution than others. A cosmopolitan Licea sp. which has been isolated frequently in other studies was not isolated in our study. This species was said to be not pollutant tolerant. Echinostelium minutum which was isolated from a more acidic environment, in a city area (14) was only found in the city area of our study. The second most diverse species Perichaena corticalis was mainly found on barks from the park and the graveyards in the city, unlike Perichaena corticalis, Cribraria violacea was found on barks from both the park, graveyard, and the streets.

Even though we do not evaluate the environmental factors that may hinder the habitat of myxomycetes in the city, we can suggest that diversity is low compared to other studies previously done in Bursa city. The collection of other types of specimens from the plants such as the fallen leaves and logs were not possible in this study due to the plants being located in the city area where these debris are swept off daily. Increasing the sample size by increasing the number of localities, may help observe many other species that were not isolated in this study. Specimens collected at different periods throughout the year may also help understand the diversity of the species at different period of the year.

The pollutants in the city area might hinder the diversity of myxomycetes, but in our study, we were able to isolate species that were never isolated from the more natural and floristic areas like the Uludağ region of Bursa, could it be that these species can easily be found in city areas? But since they were recorded in other cities outside of the city area, it could be that environmental pollutants do not affect the myxobiota.

\section{CONCLUSION}

This study provides a piece of first information on the diversity of myxomycetes in the city area and on Monumental trees of Bursa. It also added data and 6 new records for the Myxobiota of Bursa. 
The effect of urbanization on the distribution of myxomycetes can be studied at a larger scale by increasing the number of samples, collecting environmental pollutant parameters, comparing the distribution of myxomycetes in the city to those in semi-urban and the more floristic areas. This will help have a better understanding of myxomycetes distribution in the city of Bursa. Our study can serve as a basis for future studies on understanding the Myxobiota of Bursa.

Peer-review: Externally peer-reviewed.

Author Contributions: Conception/Design of study: C.C.E., F.T.; Data Acquisition: C.C.E., F.T.; Data Analysis/Interpretation: C.C.E., F.T.; Final Approval and Accountability: C.C.E., F.T.; Drafting Manuscript: C.C.E., F.T.; Critical Revision of Manuscript: C.C.E., F.T.; Technical or Material Support: C.C.E.; Supervision: C.C.E.

Conflict of Interest: The authors declare that they have no conflicts of interest.

Financial Disclosure: There are no funders to report for this submission

\section{REFERENCES}

1. Hosokawa A, Reid R C, Latty T. Slimes in the city: The diversity of myxomycetes from inner-city and semi-urban parks in Sydney, Australia. Fungal Ecol 2019; 39: 37-44.

2. Martin GW, Alexopoulos CJ. The Myxomycetes. lowa City: lowa Univ Press; 1969.

3. Stephenson SL, Stempen H. Myxomycetes: A Handbook of Slime Molds. Portland:Tim Press; 1994.

4. Kamono A, Matsumoto J, Kojima H, Fukui M. Characterization of myxomycete communities in soil by reverse transcription polymerase chain reaction (RT-PCR) - bases method. Soil Biol Biochem 2009; 41: 1324-30.

5. Smith T, Stephenson SL. Algae association with myxomycetes and leafy liverworts on decaying spruce logs. Castanea 2007; 72: 50-7.

6. Lado C, Elliasson U. Taxonomy and Systematics: Current knowledge and approaches on the taxonomic treatment of myxomycetes. Elsevier 2017; 205-51.

7. Martin GW. The contribution of de Bary to our knowledge of myxomycetes. lowa Acad Scien 1958; 65: 122-7.

8. Oran RB, Ergül CC. New Records for the Myxobiota of Turkey. Tr J Bot 2004; 28: 511-15.

9. Ocak I, Konuk M. Diversity and Ecology of myxomycetes from Kütahya and Konya (Turkey) with Four New Records. Mycobiol 2018; 46, 3: 215-23.

10. Lohwag K, Research on Turkish mycoflora. I.U.O.F Der 1957; 7: 129-37.

11. Harkonen M, Uotila P. Turkish myxomycetes developed in moist chamber cultures. Karstenia 1983; 23: 1-9.

12. Ergül CC, Gücin F. Türkiye için Yeni İki Myxomycetes Taksonu. Tr J Bot 1993; 17: 267- 71.
13. Sesli E, Akata I, Denchev TT, Denchev MC. Myxomycetes in Turkey-a checklist. Mycobiota 2016; 6: 1-20.

14. Basanta DW. Acid deposition in Madrid and corticolous myxomycetes. Stapfia 2000; 73: 113-20.

15. Ergül CC, AkgüL H. Myxomycete diversity of Uludağ national park, Turkey. Mycotaxon 2011; 116: 479-90.

16. http://www.bursa.com.tr/bursas-geography-climatepopulation?lang=en

17. Akdeniz NS, Yener DY. Bursa Uludağ and Fir. Kastamonu Univ Orm Fak. Der. 2012; Özel Sayı: 256-8.

18. Oran RB, Ergül CC. New records of corticolous myxomycetes from Turkey. Mycotaxon 2015; 130: 181-90.

19. Zencirkıran M. Determination of native landscape plants in Bursa and Uludağ. Afri J Biotech 2009; 8(21): 5737-46

20. Zencirkıran M, Akdeniz NS, Ender E, Batman ZP. The Monumental trees of Bursa and their contribution to the cultural landscape. Efe R, Curebal I, Gad A, Toth B. Environmental Sustainability and Landscape Management. Sofia: St.Kliment Ohridski Univ Press; 2016. p. 307-19.

21. Dogal Anıttır. Bursa Enviroment and Urbanization report 2014.

22. Stephenson SL, Stempen H. Myxomycetes: A handbook of slime molds. Portland.Oregon: Tim Press; 2000.

23. Ing B. The Myxomycetes of Britain and Ireland. England: The Richm Publ Co.Ltd; 1999.

24. Lado C. Nomenmyx: A nomenclature taxabase of the Myxomycetes. Cuadernos de Trabajo de Flora Micol Iberi. 2001; 16: 1-221.

25. Farr ML. Flora Neotropica, Monograph. NewYork: N.Y Bot Gard 1976.

26. Farr ML. How to know the true slime molds. Iowa USA: Wm. C. Brown comp publ 1981.

27. Discover Life. 2019 [continuously updated; viewed online in January 2019. http://www.discoverlife.org/.

28. Global Biodiversity Information Facility. 2019 [continuously updated; viewed online in January 2019. http://www.gbif.org/.

29. Nannenga-Bremekamp NE. A Guide to Temperate Myxomycetes. England: Biopress Ltd 1991.

30. Baba H. Myxomycetes of Mustafa Kemal University Campus and environs (Turkey). Tr J Bot 2012; 36: 769-77.

31. Oskay M, Tüzün Ö. Determination of the myxobiota of Kemalpaşa and surrounding (Izmir). Celal Bayar Univ J Scien 2015; 11(1):59-68.

32. Eroğlu G, Kaşik G. Myxomycete of Hadim and Taşkent districts (Konya/Turkey) and their ecology. Biol Diver Cons 2013; 6(3): 120-7.

33. Ergül CC, Dülger B. New records for the myxomycetes flora of Turkey. Tr J Bot 2001; 26: 277-80.

34. Demirel G, Kaşık G. Four new records for Physarales from Turkey. Tr J Bot 2012; 36: 95-100.

35. Ergül CC, Dülger B. The myxomycetes of Görükle (Bursa) campus area. Herb J Syst Bot 1998; 5(1): 93-6.

36. Beninde J, Veith $M$, Hochkirch A. Biodiversity in cities needs space: a meta-analysis of factors determining intra-urban biodiversity variation. Ecol Lett 2015; 18: 581-92.

37. Ergül CC, Dülger B, Oran RB, Akgül H. Myxomycetes of the Western Black Sea region of Turkey. Mycotaxon 2005; 93: 269-72. 